\title{
Histochemical Localization of Carbohydrates in Morphological Stages of Developing Human Minor Salivary Glands: A Comparative Study with Cytoskeletal Markers
}

\author{
Localización Histoquímica de Carbohidratos en el Desarrollo de Glándulas Salivales Menores \\ Humanas: un Estudio Comparativo con los Marcadores del Citoesqueleto
}

"Moacyr J. B. M. Rêgo; "Carmelita L. B. Cavalacanti; ",** Eduardo I. C. Beltrão \& *,***Ana Paula V. Sobral

REGO, M. J. B. M.; CAVALACANTI, C. L. B.; BELTRÃO, E. I. C. \& SOBRAL, A. P. V. Histochemical localization of carbohydrates in morphological stages of developing human minor salivary glands: a comparative study with cytoskeletal markers. Int. J. Morphol., 29(2):604-613, 2011.

SUMMARY: Carbohydrates play a critical role in many cellular processes like disease, growth and development. In this work lectins, proteins that recognizes carbohydrate free or conjugated, were used as histochemical probes for carbohydrates localization in developing human minor salivary gland. Immunohistochemistry for traditional cytoskeleton markers (Cks 7, 8, 13, 14, 19, SMA and Vimentin) was performed and then compared whit lectin histochemistry for PNA, WGA, ConA and UEA-I, specifics for D-galactose, Nacetyl-glucosamine, glucose/mannose and L-fucose respectively. For this, specimens were obtained from tongues and lips of 15 human foetuses at 10-28 weeks of gestation. None of immune cytoskeleton markers were identified in the first stage of development differing from carbohydrate markers. UEA-I, WGA and PNA recognized their specific carbohydrate residues in all stages analyzed varying the staining intensity and cell types. Ck8 and $\mathrm{N}$-acetyl-glucosamine were expressed in canalicular, branching and cytodifferentiation stages while SMA and glucose/mannose were observed in the cytodifferentiation stage one. ConA only recognized myoepithelial cells on cytodifferentiation stages because of this specificity ConA could be used as biomarker of myoepithelial cells on cytodifferentiation. Lectin histochemistry suggests that L-fucose, D-galactose e $\mathrm{N}$-acetyl-glucosamine are intensily and previously expressed than traditional cytoskeletal markers in human minor salivary gland during development.

KEY WORDS: Lectin histochemistry; Immunohistochemistry; Developing human minor salivary glands.

INTRODUCTION

Human minor salivary glands start to develop during 4th and 6th weeks of fetal life in a complex and coordinated way. Their formation begins with proliferation of a solid cord of cells from the epithelium of the stomatodeum into the underlying ectomesenchyme (Dale, 1994). After this four more morphological stages occur, characterized by, branching morphogenesis, lobule formation, canalization of cords and cytodifferentiation (Dale; Klein, 2002; Denny et al., 1997). To date, little is known about the regulation of cell-cell and cell-mesenchyme interaction and what sort of molecules are involved in these processes during human salivary gland development (Tucker, 2007).

Carbohydrates play important roles in development regarding their number and complexity on cell surfaces glycoconjugates which function in cellular communication (Gabius, 2000). During development and differentiation human cells express a wide array of glycan structures and control the amount and structure of such glycans with temporal and lineage specificity. This carefully orchestrated modulation of glycan diversity during development implies corresponding and important functions for these molecules (Haltiwanger \& Lowe, 2004).

Carbohydrates have an enormous potential for encoding biological information. In glycoproteins and glycolipids they dot the outer surface of all cells and serve as cellular identification tags to the surrounding world (Nangia-Makker et al., 2002). Lectins are saccharides natural cell-recognition probes and such ability has been explored

\footnotetext{
Keizo Asami Imunopatology Laboratory (LIKA), Federal University of Pernambuco (UFPE), Recife, Brazil.

** Biochemistry Department, Federal University of Pernambuco (UFPE), Recife, Brazil.

**** Oral Pathology Laboratory, Dentistry College, Pernambuco University (UPE), Camaragibe, Brazil.

Financial Support: CAPES, CNPq and FACEPE.
} 
by their use as biomedical diagnostic tools in the new millennium of a broad spectrum of diseases (Gemeiner et al., 2009). All based on their ability to decipher the glycocode on cell surface lectins are the key or "the bunch of keys" to the sugar code (Ambrosi et al., 2005; Gabius et al., 2004). In other words, whilst sugars are able to carry the biological information, lectins are capable of translating their code (Kuno et al., 2005). Thus, lectins have been used in the medical and biological areas such as in histochemistry where they can provide a sensitive detection system for changes in glycosylation and carbohydrate expression that may occur during embryogenesis, growth and disease (Campos et al., 2006).

This work aimed to evaluate the use of lectin histochemistry for characterization of cell carbohydrate profile during morphological stages in human developing minor salivary gland and compare it with cytoskeleton protein immunohistochemistry.

\section{MATERIAL AND METHOD}

Specimens. Tongues and lips samples of human foetuses $(n=15)$ at $10-28$ weeks of gestation were obtained from Professor Barros Lima and Professor Bandeira Filho Children Hospitals in Recife, State of Pernambuco, Brazil. All specimens were fixed in 10\% formalin and embedded in paraffin. Tissue sections were stained with haematoxylineosin for evaluation of morphological and developmental phases. Adult samples $(n=15)$ were used as fully developed salivary gland pattern. This work was approved by Ethical Committee of the University of Pernambuco, Brazil.

Lectin histochemistry. Four-micrometer-thick sections of specimens were deparaffinized in xyline and dehydrated in graded alcohol $(100-70 \%)$. Slices were treated with $0.1 \%$ $(\mathrm{w} / \mathrm{v})$ trypsin solution for $2 \mathrm{~min}$ at $37^{\circ} \mathrm{C}$ followed by a $0.3 \%$ (v/v) methanol- $\mathrm{H}_{2} \mathrm{O}_{2}$ solution for $30 \mathrm{~min}$ at $25^{\circ} \mathrm{C}$ and then incubated for 2 hours with lectins (Sigma, USA) conjugated to horseradish peroxidise (HRP) at $4^{\circ} \mathrm{C}$ (details in Table I). All solutions and washings were carried out using a $10 \mathrm{mM}$ phosphate buffer solution (PBS) $\mathrm{pH} 7.2$ containing $150 \mathrm{mM}$

Table I. Lectin, Sugar specificity, and working concentration in lectin histochemistry.

\begin{tabular}{lll}
\hline Lectins & Sugar specificity & Concentration \\
\hline Con A & Glusose/mannose & $80 \mu \mathrm{g} / \mathrm{ml}$ \\
WGA & N-acetyl glucosamine & $30 \mu \mathrm{g} / \mathrm{ml}$ \\
UEA-I & L-fucose & $80 \mu \mathrm{g} / \mathrm{ml}$ \\
PNA & D-galactose & $80 \mu \mathrm{g} / \mathrm{ml}$ \\
\hline
\end{tabular}

Con A - Canavalia ensiformis agglutinin, WGA - Wheat germ agglutinin, UEA-I - Ulex europaeus agglutinin, PNA - Peanut agglutinin.
$\mathrm{NaCl}$. Peroxidase was visualized with a solution of diaminobenzidine (DAB) and $\mathrm{H}_{2} \mathrm{O}_{2}$. Haematoxylin was used for counter-staining and tissues were evaluated by light microscopy. Lectin binding inhibition assays were developed by incubating lectin with its corresponding specific sugar (100 to $500 \mathrm{mM}$ ) prior to sample incubation. Negative controls were also obtained by replacing lectins with PBS and tumour samples were used as positive controls.

Immunohistochemistry. Four-micrometer-thick Sections of specimens were incubated in methanol-hydrogen peroxide $(1: 1, \mathrm{v} / \mathrm{v})$ and immune assayed with streptavidin-biotin perosidase kit (DAKO, USA). Antigenic sites were thermally recovered in steamer with $10 \mathrm{mM}$ citrate buffer at $\mathrm{pH} 6.0$. Primary antibodies, dilutions, incubation times and sources are shown in Table II. Sections were then incubated with DAB and counterstained with Mayer's haematoxylin. Negative controls were obtained by replacing the primary antibody with non-immune serum. Adult normal and neoplastic parotid glands were included as positive controls.

Table II. Primary antibody, clone, source and working dilutions used in immunohistochemistry.

\begin{tabular}{llll}
\hline $\begin{array}{l}\text { Primary } \\
\text { antibody }\end{array}$ & \multicolumn{1}{c}{ Clone } & \multicolumn{1}{c}{ Source } & $\begin{array}{c}\text { Working } \\
\text { dilution }\end{array}$ \\
\hline CK7 & OV-TL & DAKO, USA & $1: 50$ \\
CK8 & $35 b H 11$ & DAKO, USA & $1: 50$ \\
CK13 & 1C7+2D7 & DAKO, USA & $1: 50$ \\
CK14 & LL002 & Novocastra, USA & $1: 600$ \\
CK19 & BA17 & Novocastra, USA & $1: 100$ \\
SMA & 1A4 & DAKO, USA & $1: 150$ \\
Vimentin & V9 & DAKO, USA & $1: 600$ \\
\hline
\end{tabular}

Ck - Cytokeratin; SMA - Smooth Muscle Actin.

\section{RESULTS}

Bud stage. The expression of N-acetyl-glucosamine, Lfucose and D-galactose was identified in this period of development with a heterogeneous pattern of staining by, WGA, UEA-I and PNA respectively (Figs. 1a, b and c). The cells staining localization was in the cytoplasm and/or membrane. Con A, cytokeratins (CKs7, 8, 13, 14, 19), vimentin and smooth muscle actin (SMA) standings were not observed in this phase. $\mathrm{Ck} 13$ was not recognized in any glandular structure in any phase.

Canalicular stage. PNA, UEA-I and WGA, in the early period of canalization intensely recognized the central cells in apoptosis (Figs. 1d, e and f). In intermediate canalicular stage these cells were no longer stained but meanwhile their 
REGO, M. J. B. M.; CAVALACANTI, C. L. B.; BELTRÃO, E. I. C. \& SOBRAL, A. P. V. Histochemical localization of carbohydrates in morphological stages of developing human minor salivary glands: a comparative study with cytoskeletal markers. Int. J. Morphol., 29(2):604-613, 2011.

lumens begun to be stained (Figs. 1g, h and i). In the late period, next to branching stage, such cells were not recognized. Ck 8 was recognized in the ductal cells, presenting baseline or apical staining (Figs. 1j). Ck14 and
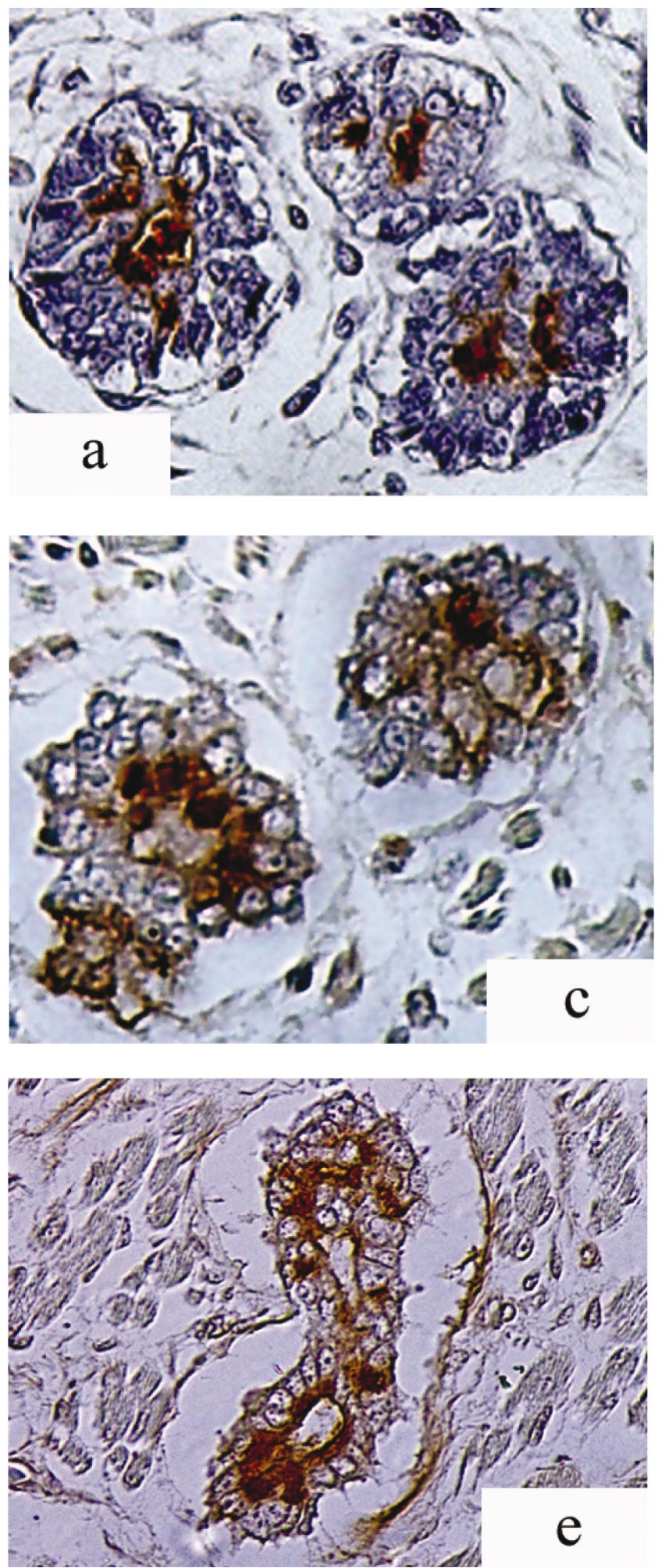

Ck19 were recognized with a heterogeneous staining pattern presenting a higher intense staining mainly in the ductal cells (Figs. 1k and 1). AML and vimentin were not observed in cells at this stage.
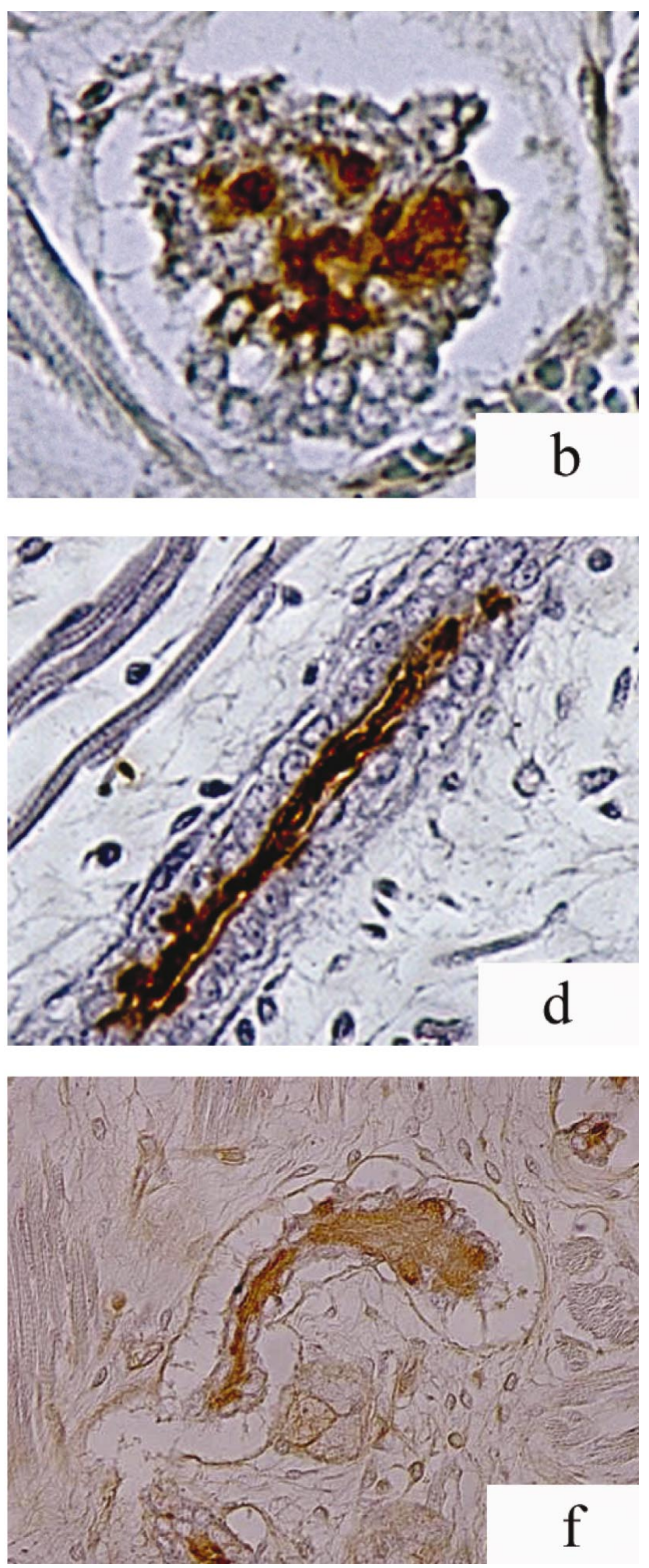

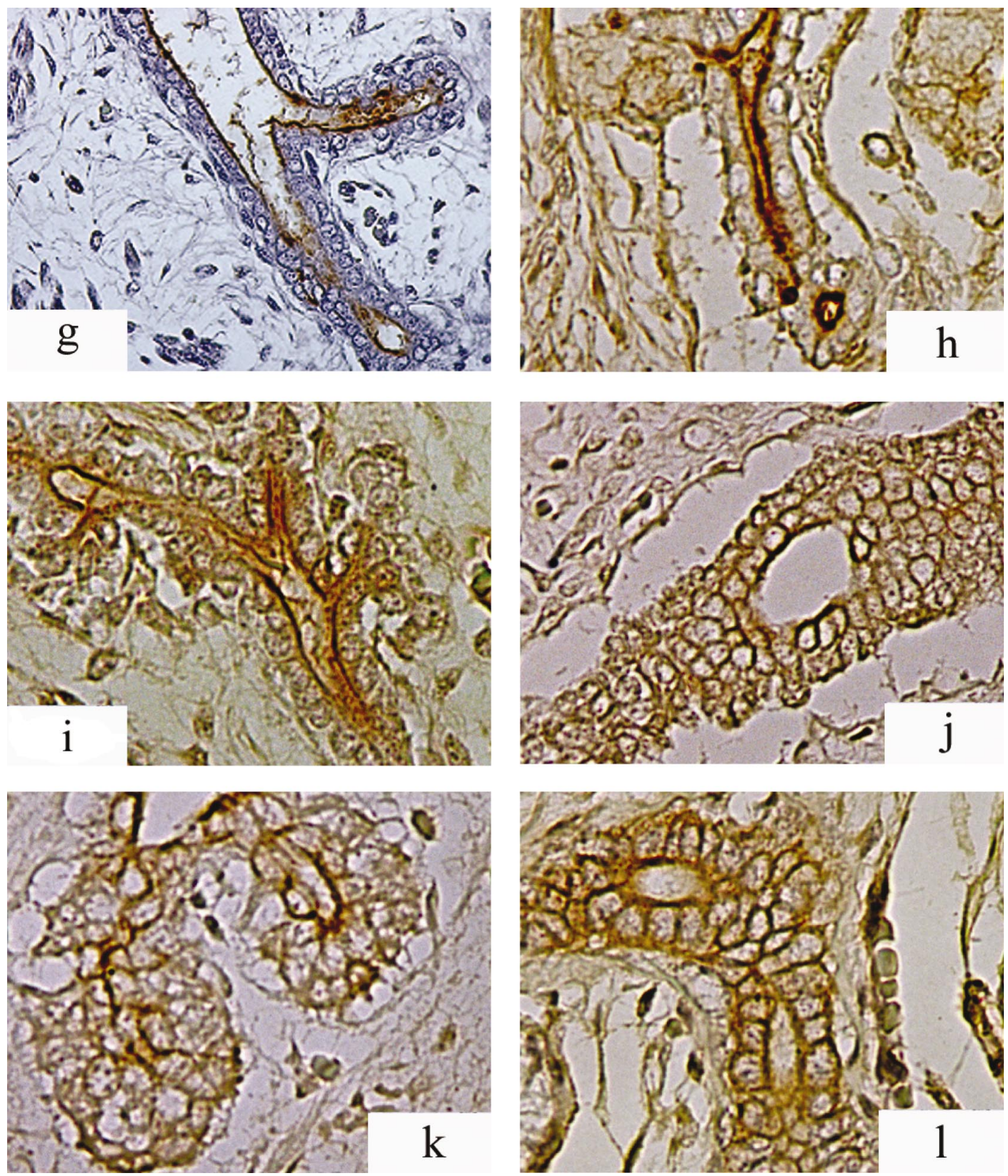

Fig. 1. Lectin histochemistry and Immunohistochemistry of bud and canalicular stages of developing human minor salivary gland. (a) PNA staining of bud central cells. WGA (b) and UEA-I (c) staining of central and peripheral cells of bud. Earlier canalicular stages showing central duct cells intensely stained with PNA (d), UEA-I (e) and WGA (f). Luminal staining of PNA (g), WGA (h) and UEA-I (i) in later canalicular stages. Ck8 (j), Ck14 (k) and Ck19 (1) staining of central and peripheral cells during canalicular stage. (Magnification $\mathrm{x} 400$ ). 
REGO, M. J. B. M.; CAVALACANTI, C. L. B.; BELTRÃO, E. I. C. \& SOBRAL, A. P. V. Histochemical localization of carbohydrates in morphological stages of developing human minor salivary glands: a comparative study with cytoskeletal markers. Int. J. Morphol., 29(2):604-613, 2011.

Branching . D-galactose and L-fucose, recognized by PNA and UEA-I, respectively, were detected with a heterogeneous staining on the majority of cells at this stage with moderate or intense staining (Figs. 2a and b). Differentially WGA recognized rudimentary acines intensely and homogeneously (Fig. 2c). Concerning
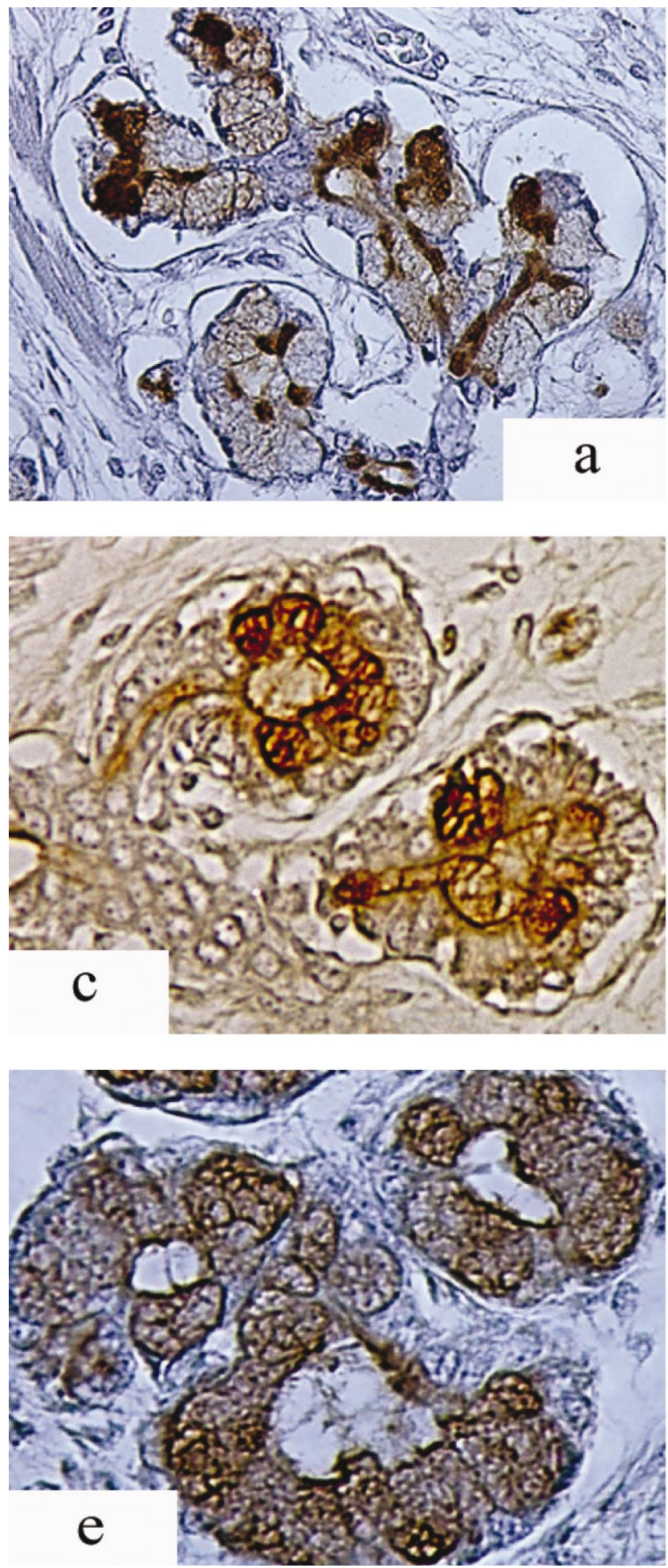

cytoskeletal markers, Ck 8 was observed in gland ducts and other Cks presented the same staining pattern of that observed in the canalization stage. Vimentin was found in stroma surrounding rudimentary acines and SMA in myoepithelial cells in some acines (Fig. 2g). Con A did not stain any structure at this stage.
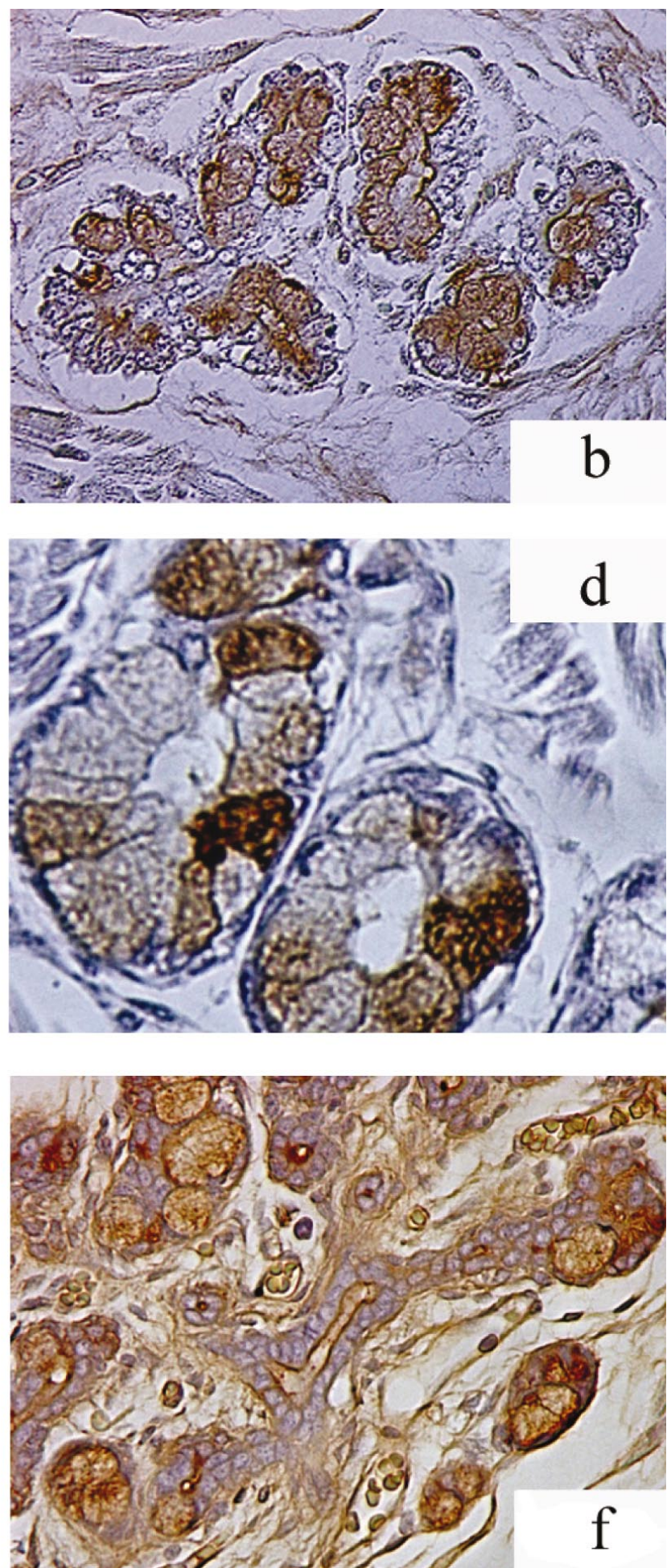

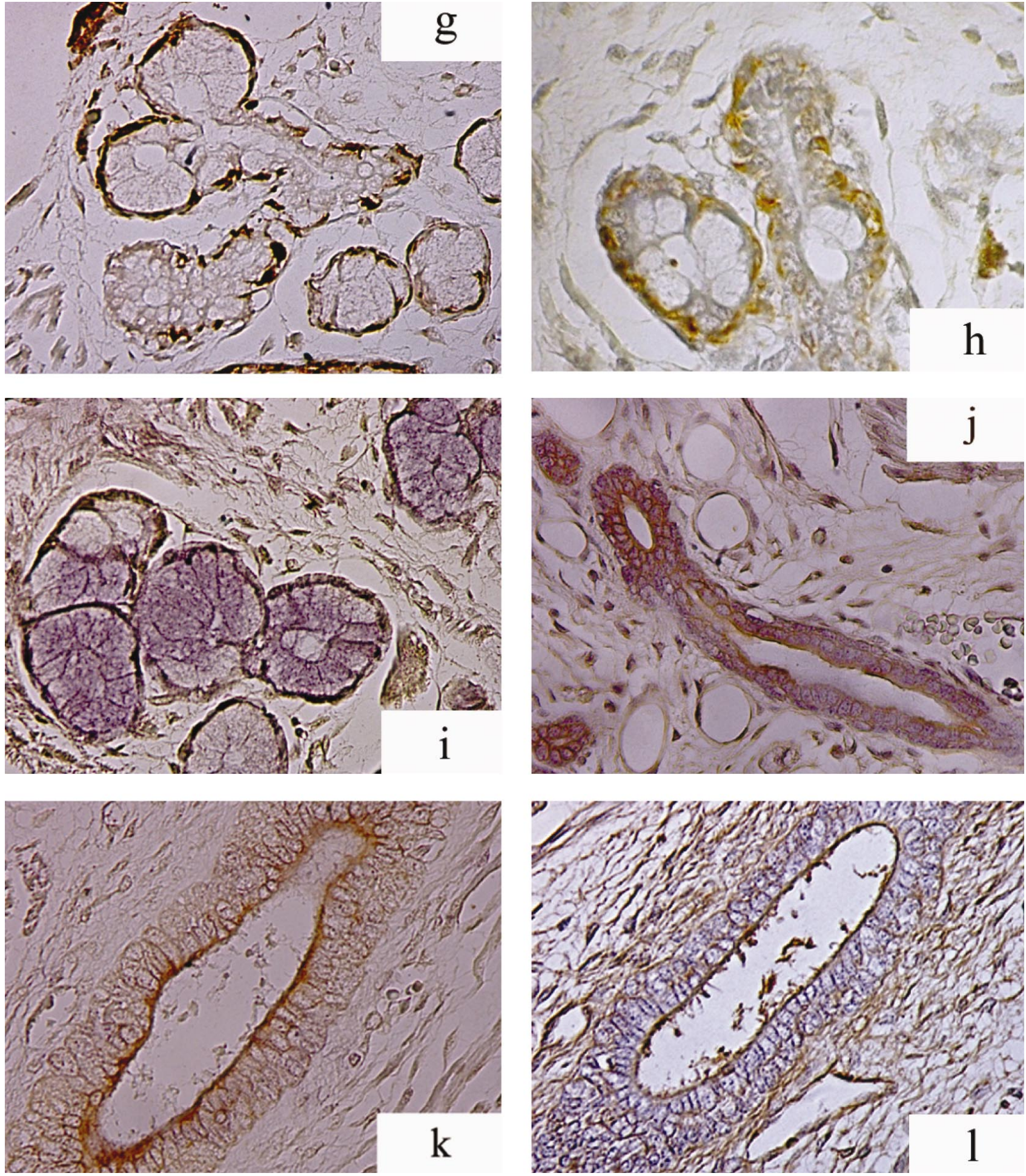

Fig. 2. Lectin histochemistry and Immunohistochemistry of branching and cytodifferentiation stages of developing human minor salivary gland. Secretory cells were recognized by PNA (a), UEA-I (b) and WGA (c). In cytodifferentiation stage PNA (d) and UEAI(e) stained secretory cells but WGA (f) only mucous cells. SMA was recognized in ending branching (g) and cytodifferentiation (h) stages only in myoepithelial cells. Con A had a similar pattern of staining (i) of SMA. Ck 14 was observed in ductal cells in cytodifferentiation stages (j). Ck 8 was found in ductal cells mainly in excretory duct cells $(\mathrm{k})$. WGA stained mainly luminal membrane of excretory duct (1). Magnification x400. 
Cytodifferentiation. PNA stained the cells of minor salivary glands at this stage in a moderate to intense pattern (Fig. 2d). Differing UEA-I homogeneously stained cytoplasm and membrane of acinar mucous and serous cells sometimes a nuclear membrane staining was also observed (Fig. 2e). WGA stained only mucous cells (Fig. 2f) and ductal cells (Fig. 21) in a similar pattern observed to CK8. Con A was the only lectin capable of recognizing myoepithelial cells (Fig. 2h) presenting a similar staining pattern that observed for SMA (Fig. 2i). Ck8 (Fig. 2k) and Ck7 stained ductal cells, Ck14 stained basal cells of excretory ducts and CK19 (Fig. 2j) stained mainly intercalated ducts. Vimentine was recognized only in stroma cells (data not shown). Cytoskeletal proteins and lectins staining in this morphological stage were similar to those observed in adults. Table III summarized the relationship between lectins and cytoskeleton proteins with stages and cell types of minor human salivary gland development.

Table III. Cytoskeleton (Immunohistochemistry) and saccharidies markers (lectin histochemistry) in relation with stages of human minor salivary gland development

\begin{tabular}{|c|c|c|c|c|c|c|c|c|c|c|c|}
\hline Stages & $\mathrm{Ck} 7$ & $\mathrm{Ck} 8$ & Ck13 & Ck14 & Ck19 & SMA & $\mathrm{V}$ & ConA & UEA & PNA & WGA \\
\hline Bud & - & - & - & - & - & - & - & - & + & + & + \\
\hline \multicolumn{12}{|l|}{ Canalicular } \\
\hline Peripheral cells & - & + & - & + & + & - & - & - & - & - & - \\
\hline Central cells & - & + & - & + & + & - & - & - & + & + & + \\
\hline \multicolumn{12}{|l|}{ Branching } \\
\hline Rudimentary acinar cells & - & - & - & - & - & + & - & - & + & + & + \\
\hline Ductal cells & + & + & - & + & + & - & - & - & + & + & + \\
\hline Ductal lumen & - & - & - & - & - & - & - & - & + & + & + \\
\hline \multicolumn{12}{|l|}{ Cytodifferentiation } \\
\hline Secretory cells & - & - & - & - & - & - & - & - & + & + & + \\
\hline Myoepithelial & - & - & - & - & - & + & - & + & - & - & - \\
\hline Ductal cells & + & + & - & + & + & - & - & - & - & - & + \\
\hline Ductal lumen & - & - & - & - & - & - & - & - & + & + & + \\
\hline
\end{tabular}

-; no staining, +; positive staining

\section{DISCUSSION}

During development the components of glycocalyx are optimally positioned to help cell communication with its environment. Carbohydrates in this structure are the most prominent surface molecules by which cells face their neighbors and molecules in the extracellular milieu (Gabius). Many papers have studied the molecular profile of proteins and their function in human oral epithelium during development (Marins et al., 2002; Lourenço et al., 2007a, 2007b, 2008). Immunohistochemistry of these proteins shows changes in function and development of salivary glands, where the pattern of expression of these biomolecules varies with the stage of development, differentiation and degree of complexity of the epithelium (Martins et al., 2002). But few studies focus on their carbohydrate profile. Adi $e t$ al. (1995) analyzed the time-related staining of some lectins in developing human minor salivary gland. However, their study does not include the morphological stages of development or the expression of glucose/mannose residues.
Until now very little is known about the mechanisms that regulate human salivary glands development, including carbohydrates. Quantitative and qualitative changes in glycosyl components of the cell surface and cytoplasm play significant roles in normal development and pathology (Ambrosi et al.).

In our results the reactivity of all intermediary filament antibodies was negative in the epithelium of the salivary glands during the bud stage. In this stage of development the epithelial cells are undifferentiated and do not exhibit any of the characteristics of the various types of cells in adults (Alberts et al., 2002). Among lectins, WGA, UEA-I and PNA recognized their specific carbohydrates $\mathrm{N}$-acetylglucosamine, L-fucose and D-galactose, respectively, in cell membranes at this stage. This pattern is similar to the membrane protein b-1-integrin in the same developmental stage of human minor salivary (Lourenço et al., 2007b). This 
staining similarity could be related to the fact that integrins surface are all major carriers of $\mathrm{N}$-glycans and their biological function and modulation are played by glycosylation (Pochec' et al., 2003). In epithelial cells, there are N-glycans of integrins with highly b1-6 N-acetyl-glucosamine branched and also had L- fucose and galactose residues ( $\mathrm{Gu} \&$ Tabigushi, 2004). This could be related with our result of lectin staining.

In the canalization stage, $\mathrm{Ck} 8$ and 19 in cells of luminal duct were found in accordance to previous studies (Martins et al.; Lourenço et al., 2007b). In the same stage, Lfucose, D-galactose and $\mathrm{N}$-acetyl-glucosamine are expressed as evidenced by UEA-I, PNA and WGA. Similar results were observed in studies with developing human sublingual gland (Chisholm \& Adi, 1995). The expression of these sugar residues was observed in the early canalization stage, decreasing during the progression of this stage, indicating that sugar is required at the moment when cellular apoptosis is intense. The expression of D-galactose and L-fucose was observed in most cells of branching stage; while WGA stained rudimentary acines and $\mathrm{Ck} 8$ was found in the ducts on this stage. A reasonable working hypothesis is that addition of $\mathrm{N}$ acetyl-glucosamine plays a role in mediating protein-protein interactions involved in organization of the cytoskeleton (Hagmann et al., 1992). Furthermore, there is clear evidence that transmembrane proteins in the endoplasmatic reticulum and the Golgi apparatus were O-GlcNA cylated on their cytosolic domains and that monosaccharides modify and modulate their membrane proteins (Gerald, 1997). The intracellular localization of endoplasmatic reticulum and Golgi membranes maybe, could explain the WGA staining next to nuclear membrane.

The cytodifferentiation of excretory cells within the rudimentary glands begins after the first canalization and branching has been established (Cutler, 1990). In our study, different patterns of cytokeratins and carbohydrates expression were observed in acinar cells. Initially these cells presented an intense staining to $\mathrm{Ck} 8,14$ and 19 that decreased with the progress of cytodifferentiation stage of development to a weak staining. Such changes in the pattern of expression of cytokeratin are directly related to the functional stage of the cycle of these cells (Araújo et al., 2000). In adults, acine cells of minor and major glands exhibit the same pattern of expression of cytokeratins in mucous and serous cells, which was not observed in lectins. UEA-I and WGA intensely stained mucous and serous cells while PNA stained moderately mucous cells and intensely in serous cells.

Vimentin was not detected in any epithelial cell at any stage of salivary gland development but it was in stromal cells (Data not shown). Previous study indicated vimentin as an early marker of differentiation in myoepithelial neoplastic cells pointing to the need of its expression during differentiation (Furuse et al., 2006).

In myoepithelial cells during development of salivary glands we observed SMA immune staining as Martins et al. SMA is an indicator of myoepithelial differentiation and its expression seems to be closely associated with natural contractibility of cell. Con A was the only lectin used in this study able to recognize their specific monosaccharides (glucose/mannose) in myoepithelial cells. These cells have a high capacity to synthesize basal lamina that is rich in glucose and mannose residues recognizable by Con A (Chisholm \& Adi). The potential link between Con A staining and SMA positivity in muscle structure/function and protein $\mathrm{O}$ mannosylation was greatly strengthened by the identification of O-mannose saccharides in $\partial$-dystroglycan. This protein bridges the actin cytoskeleton to extracellular matrix in muscle and nerve tissues (Haltiwanger \& Lowe).

Ck13 was not recognized in any structure during glandular development in accordance to other studies (Martins et al.; Poter \& Lane, 2003). Con A stained gland cells in the last week of cytodifferentiation was also observed in completely developed adult glands.

L-fucose residues were indentified mainly in branching and cytodifferentiation stages such saccharide is indicated to play critical roles in physiological processes. Experiments with knockout mice in neonatal period regarding FUT-8 activity, an enzyme that catalyse $\partial-1-6$ fucosyl addition, showed that this enzyme is crucial in Epidermal Growth Factor Receptor (EGFR) signalization implicating in possible growth retardation (Tanigushi et al., 2006). Signaling via transforming growth factor- $\beta$, previously detected by immunohistochemistry of human minor salivary glands during development Lourenço et al. (Lourenço et al., 2007b), involve d-1-6 fucosylated glycoconjugates which regulates extracellular matrix protein expression. $\mathrm{N}$-glycans core fucosylation is required for the binding of EGF to its receptor. Such carbohydrate residue, L-fucose, mediates EGFR function and the responses to EGF and TGF- $\partial$ stimulation where both regulate several biological functions including cell growth and cell differentiation (Wang et al., 2006).

The present study showed morphological evidences that sugars play important roles in salivary minor gland development. Lectin histochemistry suggests that L-fucose, D-galactose e N-acetyl-glucosamin are intensely and previously expressed than the traditional cytoskeletal markers in human minor salivary gland development and ConA also as biomarker of myoepithelial cells on cytodifferentiation. Analyses of sugar moieties of glycoconjugates will help to reveal the biological importance of glycosylation. 
REGO, M. J. B. M.; CAVALACANTI, C. L. B.; BELTR ̃̃O, E. I. C. \& SOBRAL, A. P. V. Localización histoquímica de carbohidratos en el desarrollo de glándulas salivales menores humanas: un estudio comparativo con los marcadores del citoesqueleto. Int. J. Morphol., 29(2):604-613, 2011

RESUMEN: Los hidratos de carbono tienen un papel crítico en muchos procesos celulares, como la enfermedad, el crecimiento y el desarrollo. Fueron utilizadasas lectinas, proteínas que reconocen los hidratos de carbono libres o conjugados, como sondas de localización histoquímica de los carbohidratos en el desarrollo humano de la glándula salival menor. Se realizó inmunohistoquímica de los marcadores tradicionales del citoesqueleto (CKs 7, 8, 13, 14, 19, SMA y vimentina) y posterior comparación con la histoquímica de lectinas para PNA, WGA, ConA y la UEA-I, específicas para D-galactosa, N-acetil-glucosamina, glucosa/manosa y L-fucosa, respectivamente. Para ello, se obtuvieron muestras de la lengua y de los labios de 15 fetos humanos entre 10-28 semanas de gestación. Ninguno de los marcadores inmunológicos del citoesqueleto se identificaron en la primera etapa del desarrollo, diferente de los marcadores de hidratos de carbono. UEA-I, WGA y PNA reconocen sus residuos específicos de hidratos de carbono en todas las etapas analizadas variando la intensidad de la tinción y los tipos de células. CK8 y N-acetil-glucosamina se expresaron en etapas de canalización, ramificación y citodiferenciación mientras que SMA y la glucosa/manosa se observaron solamente en la etapa de citodiferenciación. ConA sólo se reconoció en las células mioepiteliales en etapas de citodiferenciación. Así, debido a esta especificidad, ConA podría utilizarse como marcador biológico de las células mioepiteliales en la citodiferenciación. La histoquímica de lectinas sugiere que L-fucosa, D-galactosa y N-acetil-glucosamina son intensamente expresadas durante el desarrollo como los marcadores tradicionales del citoesqueleto humanos en las glándulas salivales menores .

PALABRAS CLAVE: Localización histoquímica de los carbohidratos, Inmunohistoquímica; Desarrollo de las glándulas salivares menores.

\section{REFERENCES}

Adi, M. M.; Chisholm, D. M. \& Waterhouse, J. P. Histochemical study of lectin binding in the human fetal minor salivary glands. J. Oral Pathol. Med., 24(3):130-5, 1995.

Alberts, B.; Johnson, A.; Lews, J.; Raff, M.; Roberts, K. \& Walter, P. Molecular biology of the cell. $4^{\text {th }}$ Ed. New York, Garlard Publishing, 2002.

Ambrosi, M.; Cameron, N. R. \& Davis, B. G. Lectins: tools for the molecular understanding of the glycocode. Org. Biomol. Chem., 3(9):1593-608, 2005.

Araújo, V. C.; Souza, S. O. M.; Carvalho, Y. R. \& Araújo, N.S. Application of immunohistochemistry to the diagnosis of salivary gland tumors. Appl. Immunohistochem. Mol. Morphol., 8(3):195-202, 2000.

Campos, L. M.; Cavalcanti, C. L. B.; Lima-Filho, J. L.; Carvalho-Junior, L. B. \& Beltrão, E. I. C. Acridinium ester conjugated to lectin as chemiluminescent histochemistry marker. Biomarkers, 11(5):480-4, 2006.

Chisholm, D. M. \& Adi, M. M. A histological lectin and S100 histochemical study of the developing prenatal human sublingual salvary gland. Arch. Oral Biol., 40(11):1073-6, 1995.
Cutler, L. S. The role of extracellular matrix in the morphogenesis and differentiation of salivary gland. $A d v$. Dent. Res., 4:27-33, 1990.

Dale, A. C. Salivary gland. In: Ten Cate, A. R. (ed). Oral Histology. $7^{\text {th }}$ ed. St. Louis, Mosby, 1994. pp. 312-33.

Denny, P. C.; Ball, W. D. \& Redman, R. S. Salivary glands: a paradigm for diversity of gland development. Crit. Rev. Oral Biol. Med., 8(1):51-75, 1997.

Furuse, C.; Cury, P. R.; Araújo, N. S. \& Araújo, V. C. Application of two different clones of vimentin to the diagnosis of salivary gland tumors. Appl. Immunohistochem. Mol. Morphol., 14(2):217-9, 2006.

Gabius, H. J. Biological information beyond the genetic code: the sugar code. Naturwissenschaften, 87(3):108$21,2000$.

Gabius, H. J.; Siebert, H. C.; André, S.; Jiménez-Barbero, J. \& Rüdiger, H. Chemical biology of the sugar code. Chembiochem, 5(6):741-64, 2004.

Gemeiner, P.; Mislovic`ová, D.; Tkác``, J.; S`vitel, J.; Pätoprstł, V.; Hrabárová, E.; Kogan, G. \& Kozár, T. Lectinomics. II: A highway to biomedical/clinical diagnostics. Biotechnol. Advanc., 27(1):1-15, 2009. 
Gerald, W. H. Dynamic o-lined glycosylation of nuclear and cytoskeletal proteins. Annu. Rev. Biochem., 66:315-35, 1997.

Gu, J. \& Tabiguchi, N. Regulation of integrin functions by N-glycans. Glycocoj. J., 21(1-2):9-15, 2004.

Hagmann, J.; Grob, M. \& Burger, M. M. The cytoskeletal proteins talin s o-glycosylated. J. Biol. Chem., 267(20):14424-8, 1992.

Haltiwanger, R. S. \& Lowe, J. B. Role of Glycosylation in Development. Annu. Rev. Biochem., 73: 491-537, 2004.

Klein, R. M. Development, structure, and function of salivary glands. In: Avery, J. K. (Ed). Oral development and histology. $3^{\text {rd }}$ edn. New York, Thieme, 2002. pp.352-79.

Kuno, A.; Uchiyama, N.; Koseki-Kuno, S.; Ebe, Y.; Takashima, S.; Yamada, M. \& Hirabayashi, J. Evanescent-field fluorescence-assisted lectin microarray: a new strategy for glycan profiling. Nat. Methods, 2(11):851-6, 2005.

Lourenço, S. V.; Lima, D. M. L.; Uyekita, S. H. \& Soares, F. A. Expression of beta-1 integrin in human developing salivary glands and its parallel relation with maturation markers: In situ hybridization and immunofluorescence study. Arch. Oral Biol., 52(11):1064-71, 2007 a.

Lourenço, S. V.; Uckita, S. H.; Lima, D. M. C. \& Soares, F. A. Developing human minor salivary glands: morphological parallel relation between the expression of TGF-beta. Virchows Arch., 452(4):427-34, 2008.

Lourenço, S. V.; Coutinho-Camillo, C. M.; Buim, M. E.; Uyekita, S. H. \& Soares, F. A. Human salivary gland branching morphogenesis: morphological localization of claudins and its parallel relation with developmental stages revealed by expression of cytoskeleton and secretion markers. Histochem. Cell Biol., 128(4):361-9, $2007 b$.

Martins, M. D.; Cavalcanti deAraujo, V.; Raitz, R. Soares de Araújo, N. Expression of cytoskeletal proteins in developing humam minor salivary glands. Eur. J. Oral Sci., 110(4):316-21, 2002.

Nangia-Makker, P.; Conklin, J.; Hogan, V. \& Raz, A. Carbohydrate-binding proteins in cancer, and their ligands as therapeutic agents. Trends Mol. Med., 8(4):187-92, 2002.
Pochec', E.; Litynsa, A.; Amoresano, A. \& Casbarra, A. A glycosylation profile of integrin alpha 3 beta 1 changes with melanoma progression. Biochim. Biophys. Acta, 1643(1-3):113-23, 2003.

Poter, R. M. \& Lane, E. B. Phenotypes, genotypes and their contribution to understanding keratin function. Trends Genet., 19(5):278-85, 2003.

Tanigushi, N.; Miyoshi, E.; Gu, J.; Honke, K. \& Matsumoto, A. Decoding sugar function by identifying target glycoproteins. Curr. Opin. Struc. Biol., 16(5):561-6, 2006.

Tucker, A. S. Salivary gland development. Semin. Cell Dev. Biol., 18(2):237-44, 2007.

Wang, X.; Gu, J.; Ihara, H.; Miyoshi, E.; Honke, K. \& Taniguchi, N. Core fucosylation regulates epidermal growth factor receptor-mediated intracellular signaling. J. Biol. Chem., 281(5):2572-7, 2006.

\section{Correspondence to:}

Moacyr Jesus Barreto de Melo Rêgo

Rua Professor Moraes Rêbgo s/n

Cidade Universitária

Recife - PE

50670-901

BRAZIL

Fax: + 558121268484

Tel: +558121012504

Email: moacyr.rego@gmail.com

Received: 15-12-2010

Accepted: 25-03-2011 